\title{
Urban-Rural Conflict over Framework Analysis on Media Discourses of Straw Burning in China
}

\author{
Xue-ye $\mathrm{WANG}^{1, \mathrm{a},{ }^{*}}$ \\ ${ }^{1}$ College of Journalism \& Communication, Jinan University, \\ West Huangpu Road,No.601,Tianhe District, Guangzhou, China \\ awangxueyewxy@163.com \\ ${ }^{*}$ Corresponding author
}

Keywords: Urban-Rural Conflict, Straw Burning, Discourse, Framework Analysis.

\begin{abstract}
In recent years, the phenomenon of straw burning is becoming a typical environmental conflict between urban and rural residents in China. Based on the methods of framework and content analyses, this paper pays attention to urban and rural subjects' media discourses about straw burning, which are chosen from 15 newspapers during 2010 to 2015 , including 1173 pieces of media news. The inductive results are that urban subjects - officials and citizens mainly state the frameworks of achievement and effort, pollution and accident, punishment and warning, ignorance and unruly. In contrast, rural subjects - peasants mainly present practical and helpless framework, achievement and utilization framework, as well as tradition and experience framework. Frameworks show urban subjects' discursive advantages which not only reflect in the quantity of reports, but also embody that officials and citizens are better at constructing discourses of metaphor, catch-phrase and depiction than peasants. Therefore, through power games behind urban-rural discourses and frameworks, we can conclude that urban subjects dominate rural counterparts in China.
\end{abstract}

\section{Introduction}

"Every country can't avoid encountering a core problem of urban-rural relationship in the process of modernization"[1]. Since the 1980s, with rapid progress of Chinese modernization process, the confrontations, conflicts and integrations between urban and rural areas have become inevitable realities during transition period of contemporary Chinese society. Moreover, in the 21st collective learning conference of the Political Bureau of the CPC Central Committee, whose general secretary Jin-ping XI stressed that "accelerating the integrations of urban and rural development is the strategic task, which was put forward in the 18th CPC National Congress" [2].

Mass media play an important role in constructing the relationship between urban and rural residents. In recent years, one social problem about straw burning continues to be drawn attentions by mass media in China. Urban and rural residents construct different discourses when confronting the problem of straw burning, which deduces typical urban-rural conflicts during the transformation period of contemporary Chinese society. On one hand, aimed at banning straw burning, official shung lots of red banners written with shocking slogans, such as "whoever burn straws in the morning will be detained in the afternoon", "whenever burning straws will be the jail day" and so on. Officials also decided to "fight the battle of banning straw burning as a spirit of driving nails". In addition, citizens complained "cities were surrounded by thick smoke, with which the polluted air made our breathing painful", and their "tears were choked out". On the other hand, peasants helplessly said "what could we do with 
so many straws if not burn?" And they indignantly expressed that "straw burning had been all right in the past, why it became the culprit of fog haze now?" Therefore, how to understand the urban-rural spatial relationship in contemporary China, media discourses about straw burning undoubtedly have become typical research texts.

Based on the background above, what questions this paper will discuss are that, in mass media discourses about straw burning, what main frameworks urban and rural subjects respectively use? How media discourses construct urban-rural conflicts? And what power games are presented behind the discourses of urban-rural conflicts? In order to answer these questions, this paper will firstly summarize the literatures on urban-rural conflict and discourse studies. Secondly, I will introduce the methods of framework analysis and conduct its operational process. Thirdly, through three dimensions - metaphor, catch-phrase and depiction, I'm going to analyze what main frameworks urban-rural subjects (official, citizens and peasants) mainly use in their discourse expression, behind which examine the urban-rural power relations. Finally, this paper will draw conclusions and point out further possible discussions.

\section{Literature Review}

\section{Urban-Rural Conflict}

Marx's views on urban-rural conflict provide an important reference for us to examine Chinese urban-rural conflicts today. "Marx's discussions about urban-rural opposition are mainly based on criticisms for irrational labor division under the conditions of capitalism" [3]. In other words, the contradictions between productive forces and productive relations promote the development of human society, which are often embodied in spatial dimension as the urban domination to countryside. Besides, Clive S. Thomas (1991) has predicted that future political conflict in the western United States will stem primarily from disagreement between urban and rural residents over environmental issues[4]. Freshwater and Deavers (1992) gave more definite illustrations that "the environmental conflict is becoming an urban-rural conflict as the urban majority imposes its standards of environmental quality on rural areas"[5]. Alm and Witt (1996) discovered that rural counties in Idaho tended to be less supportive of environmental protection than urban counties [6], and they attributed this split to differences in income levels, employment in natural resource-related industries, and party affiliation between urban and rural counties (Salka, 2001)[7].Ann T.W. $\mathrm{Yu}(2015)$ pointed the key causes of urban-rural conflicts in China, which included political, resourceful, environmental and cultural reasons[8].

Similarly, Chinese literatures on urban-rural conflict and confrontation are also mainly focus on macro-level research, and relevant researches are limited. For example, based on five periods of urban-rural spaces in western civilized regions symbiosis period, separation period, opposition period, equal development period and integration development period, Zhen-liang WANG (2000) pointed out that "urban-rural space opposition is the most serious period when urban economy deprive rural economy in the national economy, and China has reached a transitional period from urban-rural space opposition period to equal development period now"[9]. Jian-ping LIU and Yun-xin LI(2011) summarized six types of urban-rural conflicts, including conflicts of urban-rural residents' employment, ecological environment, resourceful acquisition, public goods supply, management system and cultural fusion[10]. The concept of spatial conflict was proposed by Lai-yi CHEN and Xiang-fu ZENG (2015): "A conflict process is based on spatial resource allocation, spatial relationship change, spatial value and meaning change, the relationships 
between space and human beings. Conflicts happening between the acquirer and the loser result from various interest relations in the process of space use"[11], which provides a basis for the review of urban-rural spatial conflict. In addition, Xiao-ning WANG (2016) analyzed the media construction for Chinese urban-rural conflict by investigating news reports in the Southern Weekend during 2007 to 2012, but she only pointed out current situations, shortcomings and suggestions in promoting harmonious development between urban and rural areas [12], which made her research lack microscopic perspective.

\section{Discourse Studies}

As for discourse studies, there are non-critical and critical methods in academe. Non-critical method pays attention to textually-oriented discourses. For instance, Fairclough defined discourse as "the ways people talking about subjects or targets, including oral, written or other forms of expression"[13]. Bakhtin regarded discourse as "an application form in specific context", and harbored a view that "discourse always contains people's specific social evaluations, such as people's active emotional reactions to historical phenomena or social environment. What's more, people's specific social evaluations not only decide their choices for words and forms, but also decide specific combination of words and forms within concrete discourses"[14].In contrast, besides the depiction for discursive text practices, critical method not only states the constructive role of discourses for social identity, social relations, knowledge and belief systems, but also present show discourses constitute the relationship between power and ideology. The representative of critical method is Foucault, who argued that "discourses are networks of meanings, symbols and rhetorics, which are committed to legitimizing the status quolike ideology"[15].Therefore, in the process of analyzing media discourses about straw burning in China, both non-critical and critical methods are going to be taken into consideration, in order to illustrate the urban-rural conflict better.

\section{Discourses of Urban-Rural Conflict under Framework Analyses}

Mass media's construction for social reality of urban-rural conflict can't be separated from the uses of reporting frameworks. Goffman, who firstly introduces the concept of framework to mass communication, argues that frameworks are important evidences, by which individuals or organizations translate social reality into subjective thinking and interpretation. He also points that framework contains two roles like choice and highlight. That is to say, in order to explain meanings, people always pick out the parts which they need, and then deal with those particularly when reporting. Afterwards, Gamson \& Modigliani (1989) defined framework as the internal structure of media texts and the central idea of organizing journalistic materials, by means of which news reports imply how audience perceive news events[16]. In the views of Stephen D. Reese (2007), framing's value as a provocative model that bridges parts of the field that need to be in touch with each other: quantitative and qualitative, empirical and interpretive, psychological and sociological, and academic and professional [17]. Therefore, through framework analysis for mass media texts, we can study how the discourses, issues and semantics are constructed, organized and processed.

In the specific process of operations, this study will adopt Gamson's media discursive package as analysis tools. Because he comprehensively presents the framing devices-metaphor, exemplar, catch-phrase, depiction, and visual image 
which are usually used in mass media reports. Metaphor always has two parts - the principal subject that the metaphor is intended to illuminate and the associated subject that the metaphor evokes to enhance our understanding. Catch-phrase is attempted summary statements about the principal subject and presented as the forms of tag-line, title or slogan, always frequently captured by commentators who are intended to suggest a general frame on events. Depiction may be presented through single-valued metaphors or exemplars or simply through some colorful string of modifiers[18].Because this paper focuses on media discourse analysis, and exemplar discourses on straw burning are very few, so this article is mainly going to analyze urban-rural subjects' discourses through three dimensions - metaphor, catch-phrase and depiction. In order to more clearly present frameworks of urban-rural conflict, this paper summarizes some high frequent words used in media discourses. What's more, when discussing urban-rural conflict behind straw burning, this paper places urban-rural subjects' discourse expression in cultural, social and powerful contexts, since "any discourses are unavoidably associated with social and historical contexts" [19].

In order to support framework analysis, this paper selects all the media reports about straw burning from 15 Chinese newspapers (5 party newspapers and 10 metropolitan newspapers) during 2010 to 2015, with a total of 1173 samples. Among them, the party newspapers, including 623 samples, are Anhui Daily, Xinhua Daily, Dazhong Daily, Hebei Daily and Hubei Daily. Metropolitan newspapers are composed of West China City News, Peninsula City News, Modern Express, Chutian Metropolis News, Dahe News, Yanzhao Metropolis News, Anhui News, China Business News, New Northern News and Beijing Times, which include a total of 550 samples. The reasons why we select these 15 newspapers are that they have typical representativeness, wide range of social influences, and have the most coverage about news of straw burning during that specific period.

Through framework analyses for media reports about straw burning, the following research will be aimed at solving these questions: in the media discourses about straw burning, what main frameworks urban and rural subjects respectively use? How urban and rural subjects construct their own frameworks? And what power games present behind urban-rural discourses?

\section{Urban-Rural Media Discourse Conflicts and Power Games on Straw Burning}

By seriously coding and reading the media reports about straw burning, this study finds that there are large differences when mass media present urban and rural subjects' discourse frameworks, which reflects not only in quantity of reports, but also in "quality" of reports - how to use the discourses of metaphor, catch-phrase and depiction.

In terms of quantity, there were 560 reports including interviews for officials and citizens, covering $47.7 \%$ of the total sample size. However, only 298 pieces of reports are connected with the peasants' interviews, which cover $25.4 \%$. When it comes to concrete reporting contents of urban discourses, mass media mainly use the frameworks of achievement and effort (86.8\%), pollution and accident (45.4\%), punishment and warning (26.8\%), ignorance and unruly (15.7\%). By contrast, rural discourses emphasize the practical and helpless framework (32.6\%), achievement and effort framework (26.5\%), and tradition and experience framework (23.8\%). Through different reporting frameworks, mass media show the discrepancy of discourses between urban and rural subjects (see table 1). 
Table1. Main Discourse Frameworks of Urban-Rural Subjects in Mass Media

\begin{tabular}{|c|l|l|l|l|l|l|}
\hline Framework & $\begin{array}{l}\text { Achievement } \\
\text { and Effort/ } \\
\text { Utilization }\end{array}$ & $\begin{array}{l}\text { Pollution } \\
\text { and } \\
\text { Accident } \\
\text { Subjects }\end{array}$ & $\begin{array}{l}\text { Punishment } \\
\text { and } \\
\text { Warning }\end{array}$ & $\begin{array}{l}\text { Ignorance } \\
\text { and } \\
\text { Unruly }\end{array}$ & $\begin{array}{l}\text { Practical } \\
\text { and } \\
\text { Helpless }\end{array}$ & $\begin{array}{l}\text { Tradition } \\
\text { and } \\
\text { Experience }\end{array}$ \\
\hline $\begin{array}{l}\text { Officials } \\
\begin{array}{l}\text { Citizens } \\
(\mathrm{n}=560)\end{array}\end{array}$ & $\begin{array}{l}\mathbf{8 6 . 8 \%} \\
(\mathbf{n = 4 8 6})\end{array}$ & $\begin{array}{l}\mathbf{4 5 . 4 \%} \\
(\mathbf{n = 2 5 4})\end{array}$ & $\begin{array}{l}\mathbf{2 6 . 8 \%} \\
(\mathbf{n = 1 5 0})\end{array}$ & $\begin{array}{l}\mathbf{1 5 . 7 \%} \\
(\mathbf{n}=\mathbf{8 8})\end{array}$ & $\begin{array}{l}3.9 \% \\
(\mathrm{n}=22)\end{array}$ & $\begin{array}{l}3.4 \% \\
(\mathrm{n}=19)\end{array}$ \\
\hline $\begin{array}{l}\text { Peasants } \\
(\mathrm{n}=298)\end{array}$ & $\begin{array}{l}\mathbf{2 6 . 5 \%} \\
(\mathbf{n = 7 9})\end{array}$ & $\begin{array}{l}8.7 \% \\
(\mathrm{n}=26)\end{array}$ & $\begin{array}{l}1.7 \% \\
(\mathrm{n}=5)\end{array}$ & $\begin{array}{l}3.7 \% \\
(\mathrm{n}=11)\end{array}$ & $\begin{array}{l}\mathbf{3 2 . 6 \%} \\
(\mathbf{n}=\mathbf{9 7})\end{array}$ & $\begin{array}{l}\mathbf{2 3 . 8 \%} \\
(\mathbf{n}=\mathbf{7 1})\end{array}$ \\
\hline
\end{tabular}

Officials and Citizens' Discourses: Frameworks of Achievement and Effort, Pollution and Accident, Punishment and Warning, Ignorance and Unruly

In media discourses, officials and citizens mainly use the frameworks of achievement and effort, pollution and accident, punishment and warning, ignorance and unruly. Specifically speaking, the framework of achievement and effort mainly involves officials make policies and regulations, carry out comprehensive utilization for straws, work hard in prohibiting behaviors of straw burning, as well as gain some achievements. The framework of pollution and accident basically emphasizes straw burning pollutes natural environment and leads to some accidents, such as traffic accidents, flight delays, bodies and plants burning and so on. Punishment and warning framework primarily refers to punishment for some local officials whose behaviors and effects of banning straw burning are not sufficient. Ignorance and unruly framework states peasants who burn straws lack awareness of environmental protection, and their behaviors are uncivilized, even are illegal.

High frequent words of the four frameworks separately are turning waste straws into treasure counterparts, comprehensive utilization, combination of solution and control; pungent taste, burnt smell, smudging, traffic accidents; administrative accountability, detention, fines; and smoke, bad habits, evil practice etc(see table 2-1).In addition, in mass media reports about straw burning, officials and citizens also use abundant discourses of metaphor, catch-phrase and depiction, which fully show the superiority of power.

Firstly, the dominance of urban subjects manifests in the use of metaphor discourses (see table 2-1). Metaphor is "a kind of thinking mechanism which can govern the formation and operation for concepts as explicit or covert ways" [20]. Metaphor is also people's way of cognizing and expressing their own experience for the world, which prevalently exists in everyday discourses, thoughts, and behaviors. In mass media reports of straw burning, officials use lots of metaphor discourses. They regard instruments for monitoring straw burning spots as "blue sky guardian", "clairvoyance", "eyes of sky", through which they are aimed at telling audience that official behaviors of banning straw burning are rational and legal for protecting natural environment and people' interests. In addition, officials make behaviors of controlling straw burning be metaphors for "new bridge defending war", "defeating the difficult battle as a spirit of driving nails", "win in the wheat harvest battle", "blocking war for straw burning" and "encirclement and suppression" etc. Through these metaphorical discourses which are connected with wars, it can tend to arouse the inherent enemy-friend relationships in audience's minds, and further illustrate official justice for governing straw burning. Therefore, discourse power is also presented as a form of metaphor power. "Metaphor power embodies the 'construction power' for similar relations between things. Powerful groups who possess the metaphor-making power can define, divide and incorporate things according to their own ideology and 
social power" [21]. Officials "construct our perceptions, our minds and our behavioral patterns" [22] through ways of metaphor discourses, then make a deep cognitive mechanism embed into human's mind.

Besides, in the framework of pollution and incidents, citizens use metaphors for "black quilts", "black maps", "black spots" and so forth to describe the ecological damages caused by straw burning. "In the meaning of metaphors, both Chinese and British nations regard black color as aberrance in contemporary psychology, and they also use black to describe and explain some mysterious, illegal, or insidious terrorist things"[23]. Furthermore, with modern rationality, citizens arouse "experience resonance which affects people's cognitions in their real life"[24]. Thus, through metaphor discourses, officials and citizens lay many understanding ways for presenting specific values, beliefs and ideologies, then construct an ideology against straw burning in subconscious level and establish the legitimacy of urban power.

Table2-1.Discourse Frameworks of Officials and Citizens

\begin{tabular}{|c|c|c|c|c|c|}
\hline \multicolumn{2}{|c|}{$\begin{array}{l}\text { Frame } \\
\text {-work }\end{array}$} & Achievement and Effort & $\begin{array}{c}\text { Pollution and } \\
\text { Accident }\end{array}$ & \multirow{2}{*}{\begin{tabular}{l}
\multicolumn{1}{c}{$\begin{array}{c}\text { Punishment and } \\
\text { Warning }\end{array}$} \\
Administrative \\
accountability. \\
Detention. Dismissal. \\
Warning. \\
Suspension. Fines. \\
Review and apology. \\
Inform and criticize. \\
Order to rectification. \\
Deduct margins. \\
One-vote veto.
\end{tabular}} & $\begin{array}{c}\text { Ignorance } \\
\text { and Unruly }\end{array}$ \\
\hline & 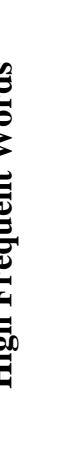 & $\begin{array}{l}\text { Monitor straw burning. } \\
\text { Monitor by satellite. } \\
\text { Policies for incentive } \\
\text { subsidy. Comprehensive } \\
\text { utilization. Turning waste } \\
\text { straws into treasure } \\
\text { counterparts. Generate } \\
\text { electricity. } \\
\text { feedstuff, methan, } \\
\text { andenergy-saving bricks. } \\
\text { Be on duty day and night. }\end{array}$ & $\begin{array}{l}\text { Dense smoke. } \\
\text { Smoke smudges. } \\
\text { Pungent taste. Burnt } \\
\text { smell, } \\
\text { Smouldering-eye } \\
\text { smoke. Respiratory } \\
\text { system diseases. } \\
\text { Traffic accidents. } \\
\text { Flight delay. Fire } \\
\text { burning. }\end{array}$ & & $\begin{array}{l}\text { Thick smoke. } \\
\text { Evil practice } \\
\text { of straw } \\
\text { burning. } \\
\text { Sneakly burn } \\
\text { straws. } \\
\text { Stubborn } \\
\text { chronic illness. } \\
\text { Resurgence of } \\
\text { bad habits. }\end{array}$ \\
\hline & 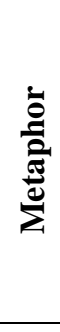 & $\begin{array}{l}\text { Guardians for blue sky. } \\
\text { Clairvoyance. Eyes of } \\
\text { sky. Guerrilla Warfare. } \\
\text { Battle for wheat harvest. } \\
\text { Blocking war for straw } \\
\text { burning. Defending battle } \\
\text { starts again in New } \\
\text { Bridge. }\end{array}$ & $\begin{array}{l}\text { Black quilts. Black } \\
\text { maps. Black spots. } \\
\text { Sea of straw fire. } \\
\text { Scorching and heat } \\
\text { waves. Smoke shells } \\
\text { attack. }\end{array}$ & $\begin{array}{l}\text { Heavy punishment } \\
\text { and administrative } \\
\text { accountability are } \\
\text { necessary to make } \\
\text { the ban on burning" } \\
\text { have long teeth". }\end{array}$ & $\begin{array}{l}\text { Battle for } \\
\text { guerrilla. } \\
\text { Resurgence of } \\
\text { bad habits. }\end{array}$ \\
\hline 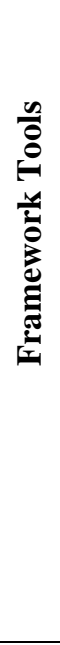 & 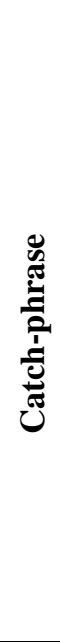 & $\begin{array}{l}\text { Defeat the difficult battle } \\
\text { for preventing straw } \\
\text { burning as a spirit of } \\
\text { driving nails. Patrol day } \\
\text { and night to ensure none } \\
\text { place appear phenomenon } \\
\text { of straw burning. Cadres } \\
\text { of different levels have } \\
\text { "the same post and } \\
\text { responsibilities". Strictly } \\
\text { defend and prevent. }\end{array}$ & $\begin{array}{l}\text { It's a sunny day } \\
\text { whenever you stop } \\
\text { to burn straws. } \\
\text { Cornfields become } \\
\text { smoke towers. } \\
\text { Smoke pervade } \\
\text { throughout all the } \\
\text { high buildings and } \\
\text { highways, with } \\
\text { which the polluted } \\
\text { air makes our } \\
\text { breaths painful. } \\
\text { Fires are blazing, } \\
\text { smoke is thick."I } \\
\text { can't see the sky } \\
\text { when looking up". }\end{array}$ & $\begin{array}{l}\text { Once find straw } \\
\text { burning, inform and } \\
\text { expose the } \\
\text { responsible } \\
\text { immediately. } \\
\text { Whoever ignites fires } \\
\text { in cornfields will be } \\
\text { imprisoned by public } \\
\text { security officers. It is } \\
\text { the day in jail } \\
\text { whenever burn } \\
\text { straws. Whoever } \\
\text { burn straws in the } \\
\text { morning will be in } \\
\text { detection in the } \\
\text { afternoon. }\end{array}$ & $\begin{array}{l}\text { Phenomena of } \\
\text { cities being } \\
\text { pervaded by } \\
\text { smoke become } \\
\text { more and } \\
\text { more. Evil } \\
\text { practice of } \\
\text { burning straws } \\
\text { is difficult to } \\
\text { solve. Thick } \\
\text { smoke } \\
\text { permeates } \\
\text { everywhere. }\end{array}$ \\
\hline
\end{tabular}

Secondly, urban subjects' dominant discourses are reflected in the construction and use of catch-phrases (see table 2-1).Officials create a list of catch-phrases for banning 
straws burning, such as "punish those responsible people once find smoke and fires from straw burning spots", "it is the day in jail whenever burn straws", "whoever burn straws in the morning will be in detection in the afternoon" etc. These catch-phrases are printed in red banners which are usually hanged near farmland or in villages. Compared with peasants, citizens are better at constructing persuasive discourses by using semiotic transformation like "paradigmatic and syntagmatic" [25] forms, which cleverly deconstruct and then reconstruct people's well-known discourses. Citizens adapt not only some lyrics such as "it's a sunny day whenever you stop to burn straws", "the polluted air with thick smoke makes our breaths painful", but also self-created Tang and Song poetries like "Qinyuanchun-smoke". Through these ways, urban subjects' catch-phrases are endowed with characteristics of literature, humor and joke, which can easily evoke people's cognition and memory systems, then make these discourses more visible by retransmission in social media. In fact, civic discourses are not always so "civilized". They also speak some catch-phrases which involve derogatory and stigmatized words, such as "evil practice of burning straws", "stubborn and chronic bad habits which are difficult to remove" and so on. These discourses will undoubtedly exacerbate urban-rural conflicts.

Finally, the discourse superiority of urban subjects is as well as presented in the construction of depiction discourses (see table 2-2). In order to get more audience's sympathies, officials often use the way of tragic narrative.

For instance, "so hot weather is aggravated by fires from straw burning, which makes village cadres sweat a lot, leading to their clothes being nearly all wet", "voice becomes dumb on account of too much calling", "have great mental stresses, feel mentally and physically exhausted, eat only two meals and sleep merely for two or three hours one day"[26]. In addition, "all rural grassroots cadres stop all other work at hand to patrol day and night. They will be punished by high-ups if supervise loosely, or will be scolded by peasants if supervise severely, which make themselves be faced with dilemmas"[27]. Therefore, officials' depiction discourses can easily arouse audience's sympathies and give them some moral shocks. In contrast, citizens always describe the process of straw burning as "smoke invasion", "smoke bomb attack", "burning the wide-area camps" etc, by which citizens use a kind of aggression and anti-aggression framework to uncover peasants' legitimacy and irrationality for burning straws, then point out their oppositions for straw burning are righteous, legitimate and self-defense. Citizens also often make seemingly rational estimates depending on their own experience and knowledge. For example, they said that peasants "usually stop their farm work at five to six o'clock in the afternoon when they would burn the straws stalked in the daytime. And since urban temperature is slightly higher than rural temperature in the evening, so air flow with smoke of straw burning would flow from rural to urban areas". Consequently, citizens effectively criticize peasants' behaviors of burning straws, express the threat to people's life and health, and then once again put civic civilization and peasants' ignorance into the focus of urban-rural contradiction. 
Table2-2.Discourse Frameworks of Officials and Citizens

\begin{tabular}{|c|c|c|c|c|c|}
\hline \multicolumn{2}{|c|}{$\begin{array}{l}\text { Frame } \\
\text {-work }\end{array}$} & $\begin{array}{c}\text { Achievement and } \\
\text { Effort }\end{array}$ & $\begin{array}{l}\text { Pollution and } \\
\text { Accident }\end{array}$ & $\begin{array}{c}\text { Punishment and } \\
\text { Warning }\end{array}$ & $\begin{array}{c}\text { Ignorance and } \\
\text { Unruly }\end{array}$ \\
\hline 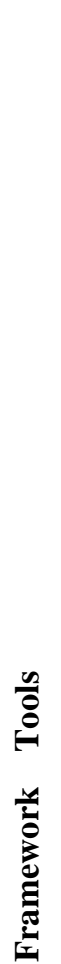 & & $\begin{array}{l}\text { Nearly } 1,000 \\
\text { households initiatively } \\
\text { put forward } \\
\text { "frankpledge" and } \\
\text { "group leader reporting } \\
\text { system". Peasants wear } \\
\text { red armbands when on } \\
\text { duty and supervise each } \\
\text { other, group leader } \\
\text { inspect and report to the } \\
\text { high-up every day } \\
\text { during the period of } \\
\text { wheat harvest. } \\
\text { Municipal party } \\
\text { committee secretaries } \\
\text { and mayors supervise in } \\
\text { villages, where county } \\
\text { and township leaders } \\
\text { have to live to supervise } \\
\text { straw burning. Officers } \\
\text { walk and propagandize } \\
\text { regulations door to door } \\
\text { for peasants, which } \\
\text { make them tired. }\end{array}$ & $\begin{array}{l}\text { "These burning } \\
\text { straws cause so } \\
\text { much thick } \\
\text { smoke and } \\
\text { greenhouse } \\
\text { effect"."My tears } \\
\text { were choked } \\
\text { out"."I was } \\
\text { choked awake by } \\
\text { a kind of intense } \\
\text { smell in the } \\
\text { morning. I looked } \\
\text { out through the } \\
\text { window and } \\
\text { found the air was } \\
\text { gray." "My } \\
\text { hometown is in } \\
\text { rural area, so I } \\
\text { know the taste } \\
\text { must come from } \\
\text { burning wheat } \\
\text { straws." }\end{array}$ & $\begin{array}{l}\text { Officers whose } \\
\text { responsible areas } \\
\text { appear "the first } \\
\text { fire" will suffer } \\
\text { from administrative } \\
\text { accountability. Once } \\
\text { find straw burning } \\
\text { spot, relevant } \\
\text { official who has to } \\
\text { keep watching in } \\
\text { countryside will be } \\
\text { deposed locally. } \\
\text { Government repeats } \\
\text { orders and } \\
\text { injunctions to } \\
\text { prevent straw } \\
\text { burning. Fines of } 20 \\
\text { million yuan can } \\
\text { make a county who } \\
\text { lacks financial } \\
\text { revenue feel } \\
\text { distressed. }\end{array}$ & $\begin{array}{l}\text { "All others } \\
\text { burn straws, } \\
\text { who care my } \\
\text { incineration?"" } \\
\text { I persuaded } \\
\text { them not to } \\
\text { burn straws, } \\
\text { but it didn't } \\
\text { work." } \\
\text { Peasants would } \\
\text { neither care nor } \\
\text { obey } \\
\text { regulations at } \\
\text { all. Peasants } \\
\text { just burn straws } \\
\text { whenever they } \\
\text { want Farmers } \\
\text { still furtively } \\
\text { burn straws } \\
\text { since they think } \\
\text { it's convenient } \\
\text { to cultivate. }\end{array}$ \\
\hline
\end{tabular}

Peasants' Discourses: Frameworks of Practical and Helplessness, Achievement and Utilization, Tradition and Experience

In the media reports, peasants mainly use frameworks of practical and helplessness, achievement and utilization, tradition and experience. Specifically speaking, practical and helplessness framework basically refers to peasants' consideration for economic and available factors for straw burning, such as high payments and low acquisitions for recycling straws, expenditure of time and laborious, lacking youth labor forces in rural areas, having no enough places to pile up too many straws etc. Compared with urban framework, rural subjects as well as use the framework of achievement and utilization, but meaning scope in the context of peasants' discourses obviously shrink and focus on emphasizing their agreements with the achievement of comprehensive utilization for straws. What's more, tradition and experience framework not only states burning straws as peasants' traditional planting experience that can produce fertilizers and prevent pests and diseases, but also stresses smoke from straw burning can evoke someone's poetic and nice memories for their rural experiences in early years, which exist in traditional agricultural civilization. Relevant high frequent words for frameworks of peasants' discourses include saving time and strength, retrenching cost, convenience, reducing pests, making fertilizers and so on (see table 3 ).

Compared with officials and citizens, peasants' discourse resources are relatively and obviously scarce. In other words, peasants can't use metaphorical discourses, and only use a few catch-phrase and depiction discourses, which present colloquial features. For instance, peasants said, "what I can do using straws if wouldn't burn them?" "I can give you 20 yuan, could you carry the straws out for me?" The reason why peasants said helplessly has close relation with time commoditization, "which is potentially connected with a phenomenon of labor's commodification"[28]. For rural 
peasants, "the commoditization of time has become a kind of resource for obtaining material wealth. Therefore, they neither want to spend time, nor do pay for the cost of labor and material forces to clean up straws. "They also hate hazes and want to breathe fresh air, but it is too extravagant for them to pay 60 to 80 yuan per mu to deal with straws"[29]. So peasants "simply burn a straw, which is the freest and easiest method for them". This precisely explains urban conquest for rural areas. That is to say, "the capitalist production mode extend from cities to rural spaces, which makes all the activities in countryside have to be subordinated to the need for capital appreciation" [30].

Table3. Discourse Frameworks of Peasants

\begin{tabular}{|c|c|c|c|}
\hline & $\begin{array}{l}\text { Frame } \\
\text {-work }\end{array}$ & Practical and Helplessness & \multirow{2}{*}{\begin{tabular}{l}
\multicolumn{1}{c}{ Tradition and Experience } \\
Prevent pests and diseases of \\
corps. Make fertilizers. \\
Smoke from kitchen chimneys.
\end{tabular}} \\
\hline & 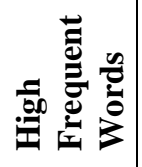 & $\begin{array}{l}\text { Save/waste time and strength. Retrench cost. } \\
\text { Lack labor forces and material resources. Farm } \\
\text { on time. For convenience. }\end{array}$ & \\
\hline & 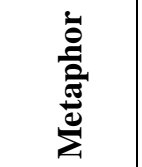 & Nothing & Nothing \\
\hline & 方 & $\begin{array}{l}\text { "What other functions straws have if not burn } \\
\text { them?" "Both labor forces and material resources } \\
\text { are relatively scarce". "I give you } 20 \text { yuan, could } \\
\text { you carry the straws out for me?" }\end{array}$ & $\begin{array}{l}\text { Slash-and-burn cultivation is a } \\
\text { good method of dealing with } \\
\text { straws since ancient times. }\end{array}$ \\
\hline 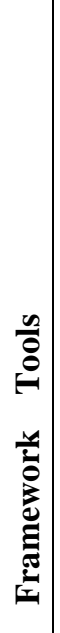 & $\frac{0}{0} \cdot \frac{0}{0}$ & $\begin{array}{l}\text { "I know there is pollution, and I will suffer from } \\
\text { the smoke of straw burning firstly. But it's } \\
\text { convenient to burn straws, which also makes } \\
\text { cornfields fertile."Nowadays, rural living } \\
\text { conditions are improved and most of rural youth } \\
\text { labor forces work in cities, peasants don't use } \\
\text { straws for cooking, nor do they raise livestock, so } \\
\text { straws become useless. Collecting, transporting, } \\
\text { crushing and selling straws spend so much time } \\
\text { and money for hiring labors and grinders, the } \\
\text { result of which means obtaining only a little } \\
\text { money even losing money."In order to plant on } \\
\text { time, we have to burn straws, which are the most } \\
\text { convenient method." There are too many straws } \\
\text { to place at home. }\end{array}$ & $\begin{array}{l}\text { How many poetic and nice } \\
\text { memories about smoke of straw } \\
\text { burning from kitchen chimneys } \\
\text { have evoked in thousands of } \\
\text { years? Strawburning has been } \\
\text { all right in the past, why it } \\
\text { becomes the culprit of hazes } \\
\text { now? No person don't like } \\
\text { smoke form kitchen chimneys } \\
\text { which carry homesickness and } \\
\text { memories. Burning straws also } \\
\text { have helpful functions, such as } \\
\text { burning grass seeds to death } \\
\text { and generating fertilizers. }\end{array}$ \\
\hline
\end{tabular}

In the framework of tradition and experience, peasants use some catch-phrases, such as "if we didn't burn straws last year, plant diseases and insect pests must highly appear next year". However, most of peasants' catch-phrases are based on summaries for agricultural experience, which result in their amount of discourses are far fewer than officials' and citizens'. When peasants "fail to show external concrete images or can't be supported by significant tangible evidences, it's difficult to impress or penetrate the general consciousness of community"[31]. Moreover, although some citizens coming from countryside think that smoke from kitchen chimneys carry and bring many homesickness and memories - "how many good and poetic memories about smoke from kitchen chimneys have evoked in thousands of years" ? "straw burning has been all right in the past, why it now becomes the culprit of hazes?"- this 
kind of views are only a few. Therefore, peasants' discourses are in a distinct disadvantage position when placed in the power games of urban-rural conflict.

\section{Conclusions and Discussions}

Straw burning is a typical social problem in Chinese social transitional period when encountering crisis of modernity. Based on framework analyses about mass media discourses of straw burning, this paper expounds Chinese urban-rural conflicts and power games by summing up the reporting frameworks mainly used by urban and rural subjects - officials, citizens and peasants. It is found that urban subjects' discourse advantages not only reflect in the abilities of construction and communication for metaphor, catch-phrase and depiction discourses, but also present in quantity of discourses urban and rural subjects use. In the samples of mass media coverage about straw burning, the number of mass media coverage involved interviews for urban subjects is 560 pieces, while the amount for rural subjects' interviews is only 298 pieces. In addition, most reports about peasants show positive or neutral sentiments $(75.8 \%)$. In other words; media discourses tend to represent peasants' affirmative attitudes on comprehensive utilization for straws, while the frequency of helplessness for peasants' straw burning is very low in media.

Foucault said that discourse is the foundation of power, and discourse is committed to legalizing the status quo. That is to say, discourse is not only a kind of cognitive tool, but also a sort of "existence and power with substantive property". Bourdieu, a sociologist, also discussed "the relationship between language and space"[32], and pointed out that language is an expression tool, a kind of culture and symbolic power. It is through the possession, control and innovation for the languages that social interest groups continue to strengthen their own discourse power. Imbalance of urban-rural subjects' discourses leads to unequal power and the distortion of urban-rural relationship. In addition, Foucault believed discourses contain abstract, theoretical conceptual constructions, as well as knowledge and power implicitly imply each other. "There is no power relationship without construction of knowledge, and there is also no production of knowledge without power relations as prerequisites"[33]. In the process of constructing issues about straw burning, urban subjects devote themselves to the production of knowledge discourses, while rural subjects primarily summarize their experience discourses. This shows that "in the process of urban-rural separation and confrontation, city has always dominated countryside"[34]. It is similar to "Marxist class criticisms about unfair production, which ultimately embody in the domination and disciplinary practices from one space to the other"[35].

However, the situations mass media present may not represent the real practices of urban-rural conflict. Because with the development of social media, Cenozoic peasants as important rural groups continue to participate in the process of discourse interactions and power games between urban and rural subjects, which put the topic about straw burning into a new and dynamic procedure. So the complexity of the problem of straw burning is how to regard Chinese urban-rural relationship in modern contexts. Moreover, "the antagonism between urban and rural areas began with the transition from barbarism to civilization, from local limitations to nationalities, which permeate the history of all civilizations and continue to the present"[36]. Since "cities are generators for authoritative resources, through which state power can be established and maintained"[37]. Therefore, we need further research the interaction between urban and rural subjects through social media, and under more specific social 
and historical contexts, to understand the complicated and dynamic urban-rural relationship better.

\section{Acknowledgement}

I would like to thank my tutor professor Tao LIU for guidance, and thank Meng-lin WU, Li-ying XIAN and Jing-wen YAN for helping collecting media reports.

\section{References}

[1]Wen-bin YI, The Historical and Theoretical Explanations for the Evolution of Urban-rural Relations, Journal of Henan University (Social Science), May2010, Vol.50, No.3, p.61.

[2] Jin-ping XI, Improve the Integration Mechanism of Urban and Rural Areas and Make Farmers Share the Achievement, Xinhua News Agency, May 1, 2015,

http://www.chinanews.com/gn/2015/05-01/7247443.shtml

[3][34]Jian-guo GAO, New Marxist Urban Theory, Beijing: The Commercial Press, 2006, p.53/52.

[4][7]Salka, W. M., Urban-rural Conflict over Environmental Policy in the Western United States, The American Review of Public Administration, March 2001, Vol. 31, No. 1, p.33/37.

[5] Freshwater, D. \& Deavers, K., Falling Farther Behind: Current Conditions in Rural America. InR. D. Bollman (Eds.), Rural and Small Town Canada, Toronto, Canada: Thompson Educational, 1992, p.62.

[6] Alm, L. R., \&Witt, S. L., The Rural-urban Environmental Conflict in the American West: A Four State Study, Spectrum, Fall1996, pp. 26-35.

[8] Ann, T. W., Wu, Y., Shen, J., Zhang, X., Shen, L., \& Shan, L., The Key Causes of Urban-rural Conflict in China, Habitat International, 2015,Vol.49, p.66.

[9] Zhen-liang WANG, The Theory of Urban-Rural Integration: A Systematic Study of Urban-Rural Relations in the Process of Urbanization Sustainable Development in China, Shanghai: Fudan University Press, 2000, p.35/73/105.

[10] Jian-ping LIU \& Yun-xin LI,Urban-rural Conflict and Causes in the Process of Rapid Urbanization, Theoretical Monthly,2011, No.12, p.5.

[11]Lai-yi CHEN \& Xiang-fu ZHENG, A Rational Reflection on Contemporary Urban Spatial Conflict, Zhejiang Social Sciences, 2015, No.6, p. 77.

[12] Xiao-ning WANG, Urban- Rural Conflict in Media Vision-A Case Study of "Southern Weekly" (2007-2012), Journal of Zhengzhou University(Philosophy and Social Sciences),May 2016, Vol.49, No.3, p.150.

[13]Norman Fairclough, Discourse and Social Change, Xiao-rong YIN trans., Beijing: Huaxia Press, 2003, p.1/3/35.

[14]MinYANG, The Social and Political Interpretation of Discourse, Beijing: Guangming Daily Press, 2015, p.27. 
[15] Yong-guo CHEN, Discourse. In ZHAO Yi-fan (Eds.), Key Words in Western Cultural Theory, Beijing: Foreign Language Teaching and Researching Press,2006, p.226.

[16] Ya-lan HUANG \& Yun-xi QIU, Fractured Imagination of Taiwan's National Identity: A Framing Analysis of Media Coverage on "Xi-Ma Meeting", Journalism Bimonthly, 2016, No.1, p.130.

[17] Stephen D. Reese, The Framing Project: A Bridging Model forMedia Research Revisited, Journal of Communication, 2007,Vol.57, No.1,p.148.

[18] Gamson, W.A. , \&Lasch, K. E., The Political Culture of Social Welfare Policy. In S.E. Spiro \& E.Yuchtman-Year(Eds.), Evaluating the Welfare State: Social and Political Perspectives, New York: Academic Press, 1983, p.411.

[19][33] Olsson, M. R., Michel Foucault: Discourse, Power/Knowledge, and the Battle for Truth. In Gloria J. Leckie, Lisa M. Given \& Join E. Buschman(Eds.), Critical Theory for Library and Information Science, 2010, p.65/67.

[20][21] Bao-zhu LIN, The Ideological Power of Metaphor, Xiamen: Xiamen University Press, 2012, p.25/110.

[22] Lakoff, G \& Johnson, M., Metaphors We Live By. Chicago: University of Chicago Press, 1980, p.5.

[23] Yi SUN,Multidimensional Cross Domain Studies for Cognitive Metaphors,Beijing: Peking University Press, 2013, p.213.

[24] Cohen, I. G., \& Blavin, J. H.,"Gore, Gibson, and Goldsmith: The Evolution of Internet Metaphors in Law and Commentary", Harvard Journal of Law \& Technology, Vol.16, No.1, Fall2002, p.267.

[25] Yi-heng ZHAO, Semiotics, Nanjing University Press, 2012, p.160.

[26] Yun XING, Straw Burning in Hebei Province: High-Pressure Monitoring is Difficult to Solve the Essential Problem, October 24, 2011,

http://tousu.hebnews.cn/2011-10/24/content_2334641.htm

[27] Jian-feng ZOU, Banning Straw Burning, Why not Ban Setting off Firecrackers,Xinhua Daily, January 15, 2014,

http://xh.xhby.net/mp2/html/2014-01/05/content_929647.htm

[28][37] Anthony Giddens, A Contemporary Critique of Historical Materialism, Zhong-hua GUO trans., Shanghai: Shanghai Translation Press, 2010, p.132/149.

[29]Zhi-an WANG, You Want Blue Sky in CitiesBut It Doesn't Mean Justice, Global Times, October 23, 2015,

http://news.cyol.com/content/2015-10/23/content_11739327.htm

[30] JiangSUN,Space Production-From Marx to the Present Age, Beijing: Renmin Press,2008, p.41.

[31] Walter Lippmann, Public Opinion, Ke-hong YAN \& Hong JIANG Trans., Beijing: Commercial Press, 2002, p.86. 
[32] Pierre Bourdieu, What Language Means: The Economy of Language Exchange, CHU Si-zhen Trans., Beijing: The Commercial Press, 2005, p.17.

[35] Tao LIU,Risk, Mobility and Critique of "Uncertainty": A Paradigm to Marxist Class Analysis, Nanjing Social Sciences, 2016, No.5, p.96.

[36] Marx\& Engels, German ideology.In Complete Works of Marx and Engels, Beijing: Renmin Press,1960, p.56-57. 